\title{
Zamansal ve mekansal değişimlerin eski göl tabanlarındaki toprak oluşumu, gelişimi ve morfolojisi üzerine etkisi
}

\section{Temporal and spatial changes in old lake bottom effect on soil formation, development and morphology}

\author{
Gafur GÖZÜKARA ${ }^{1 *}$, Sevda ALTUNBAŞ² iD, Mustafa SARI² id \\ ${ }^{1}$ Eskişehir Osmangazi Üniversitesi, Ziraat Fakültesi, Toprak Bilimi ve Bitki Besleme Bölümü, Eskişehir \\ ${ }^{2}$ Akdeniz Üniversitesi, Ziraat Fakültesi, Toprak Bilimi ve Bitki Besleme Bölümü, Antalya
}

\section{To cite this article:}

Gözükara, G., Altunbaş, S. \& Sarı, M. (2020). Zamansal ve mekansal değişimlerin eski göl tabanlarındaki toprak oluşumu, gelişimi ve morfolojisi üzerine etkisi. Harran Tarım ve Gıda Bilimleri Dergisi, 24(1): 96110.

DOI: 10.29050/harranziraat.581874

\section{Address for Correspondence:} Gafur GÖZÜKARA

e-mail:

ggozukara@ogu.edu.tr
Received Date: 25.06.2019 Accepted Date: 29.01.2020

(C) Copyright 2018 by Harran University Faculty of Agriculture. Available on-line at www.dergipark.gov.tr/harranziraat

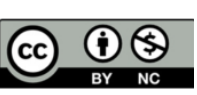

\section{öz}

Bu çalışmanın amacı Burdur Gölü’nün eski ve güncel göl tabanlarında zamansal ve mekansal farklılıkların toprakların pedogenetik gelişimi ve özellikleri üzerine etkilerini belirlemektir. Araştırma kapsamında eski ve güncel göl tabanları üzerinde gelişen kuvaterner yaşı 8 pedon tanımlanmıştır. Kuvaterner dönemi boyunca devam etmekte toprak oluşum faktörlerinin araştırma alanı içerisindeki profillerde B horizonunun oluşabilmesi için yeterli olmadığı, fakat toprak oluşum faktörlerinin profillerde zamansal ve mekansal farklılıklara bağlı olarak toprakların morfolojik, fiziksel ve kimyasal özellikleri üzerinde önemli farklılıklar oluşturmuştur. Bu farklılıklar toprak profillerinde; $\mathrm{pH}$ değerlerini 7.54-9.53, tuz içeriklerinin 0.31-18.11 dSm${ }^{-1}$, kireç içeriklerinin \%12.06-48.20, organik madde miktarlarının \%0.32-4.40, kil içeriklerinin \%7.60-83.09, suda çözünebilir anyonlardan; $\mathrm{CO}_{3}{ }^{-2}$ ın $0.12-2.96$ meq ${ }^{-1}, \mathrm{HCO}_{3}{ }^{-\prime}$ ın

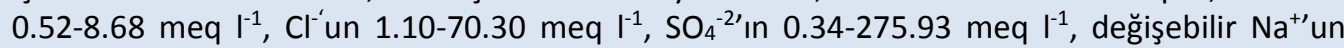
0.14-34.72 meq $100 \mathrm{~g}^{-1}$, değişebilir $\mathrm{K}^{+\prime}$ un 0.07-1.02 meq $100 \mathrm{~g}^{-1}$, değişebilir $\mathrm{Ca}^{++}+\mathrm{Mg}^{++}$un 9.1249.67 meq $100 \mathrm{~g}^{-1}$, katyon değişim kapasitesinin (KDK); $13.69-60.52 \mathrm{meq} 100 \mathrm{~g}^{-1}$, değişebilir sodyum yüzdesinin (ESP) ise $0.80-71.36$ arasında değişmesine sebep olmuştur. Toprakların morfolojik, fiziksel ve kimyasal özelliklerindeki zamansal ve mekansal farklııklar Burdur Gölü’nün güncel göl sınırlarına yaklaştıkça pedogenetik ayrışma-değişim-dönüşüm süreçlerinin oldukça azalmasına neden olmuştur. Elde edilen bu veriler alandaki arazilerin planlanmasında kullanılarak günümüzde dramatik bir şekilde yok oluşa doğru giden Burdur Gölü’nün ve çevresinin korunması ile ekolojik devamlılığının sağlanmasına katkı sağlayacaktır.

Anahtar Kelimeler: Burdur Gölü, Lakustrin ana materyal, Toprak oluşumu ve gelişimi

\section{ABSTRACT}

The aim of this study is to determine the effects of temporal and spatial differences on the pedogenetic development and properties of soils in the old and current lake bottom of Burdur Lake. Within the scope of the research, 8 quaternary pedons developed on old and current lake bottom were identified. soil formation factors during the Quaternary period were'nt sufficient for the formation of the B horizon in the profiles in the study area, but the soil formation factors caused significant differences in the morphological, physical and chemical properties of soils due to the temporal and spatial differences in the profiles. These differences in soil profiles; $\mathrm{pH} 7.54-9.53$, salinity $0.31-18.11 \mathrm{dS} \mathrm{m}^{-1}$, lime $12.06-48.20 \%$, organic matter content $0.32-4.40 \%$, clay content $7.60-83.09 \%$, water soluble anions; $\mathrm{CO}_{3}{ }^{-2} 0.12-2.96$ meq ${ }^{-1}, \mathrm{HCO}_{3}^{-}$0.52-8.68 meq I-1, Cl-1.10-70.30 meq I ${ }^{-1}, \mathrm{SO}_{4}^{-2}$ 0.34-275.93 meq I-1, exchangeable; $\mathrm{Na}^{+}$content $0.14-34.72$ meq $100 \mathrm{~g}^{-1}$, $\mathrm{K}^{+}$content $0.07-1.02$ meq $100 \mathrm{~g}^{-1}$, $\mathrm{Ca}^{++}+\mathrm{Mg}^{++}$content 9.12-49.67 meq $100 \mathrm{~g}^{-1}$, cation exchange capacity (KDK); $13.69-60.52$ meq $100 \mathrm{~g}^{-1}$, exchangeable sodium percentage (ESP); $0.80-71.36$ caused the change. The temporal and spatial differences in the morphological, physical and chemical properties of the soils have led to a significant reduction in pedogenetic decomposition-change-transformation as it approaches the current lake boundaries of Burdur Lake. These data will be used in the planning of the lands in the area and will contribute to the conservation and ecological sustainability of the Burdur Lake and its environment, which is now dramatically disappearing.

Key Words: Lake Burdur, Lacustrine anamaterial, Soil formation and development 


\section{Giriş}

Göller, genellikle bulundukları yörenin en çukur topografyalarında yer alırlar. Bu ortamlar, bulundukları topografyaları gereğince çevrelerindeki yüksek arazilerden oluşan dönemsel yüzey akışlarıyla taşınan taşlı-topraklı materyaller tarafından doldurulmaktadır. Göllerdeki su ve dalga hareketleri ile zaman içerisinde organize olan ve göl tabanlarında düz ve düze yakın bir topografik yapı oluşturan bu materyaller Jeoloji Biliminde "lakustrin" olarak isimlendirilir (Sarı, 2015; Gözükara ve Altunbaş, 2016; Soil Survey Manuel 2017). Binlerce ve/veya onbinlerce yıl boyunca su altındaki havasız ortamlarda kalmış olan bu materyaller, göllerdeki su seviyesinin çeşitli nedenlerle düşmesi neticesinde yer yer gölün kuruması ile tamamen sudan kurtularak karasal ortama çıkarlar. Karasal ortamın ekolojik unsurları ile karşılaşan ve toprak oluşumu kapsamında farklı değişim ve dönüşüm olaylarını yaşamaya başlayan bu jeolojik materyaller, Toprak Biliminde "lakustrin ana materyal" olarak isimlendirilmektedir (Sarı, 2015; Soil Survey Manuel, 2017). Gerek depolanmaları ve gerekse karasal ortama çıkışları kapsamında zamansal ve mekansal farklılıkları bulunan bu lakustrin ana materyaller üzerinde oluşumları devam etmekte olan toprakların morfolojik, fiziksel, kimyasal ve mineralojik özelliklerinde önemli farklııklar bulunmaktadır. Bu farklılıkların toprakların üretkenlik potansiyelleri ve kullanım şekillerinin belirlenmesi üzerinde etkili olduğu belirtilmiştir (Sarı ve ark., 2003; Altunbaş ve Sarı, 2010; 2011; Gözükara, 2019; Gözükara ve ark., 2019a). Toprak oluşumu ve gelişimi için zaman ve mekan faktörleri toprakların özelliklerini ve onların ayrışma oranlarını belirlemektedir. Bu etki zamanla morfolojik, fiziksel, kimyasal ve mineralojik özelliklerin değişimi ve gelişimi ile değişik sayılarda horizonların oluşmasını ve farklılaşmasını sağlamaktadır (Sarı ve ark., 2003; Mutlu, 2010; Altunbaş ve Sarı, 2011; Gözükara, 2019; Gözükara ve ark., 2019a). Bu farklılaşma başlangıç olarak elementlerin toprak profili içinde yeniden dağılımı, horizonlaşması ve son olarak da bu dağılıma bağı olarak toprak tiplerinin farklılaşması olarak ortaya çıkar (Jenkins ve Jones, 1980). Ancak toprak oluşumu için geçen zaman aynı olsa bile diğer toprak yapan faktörlerin farklı oranlardaki etkisi ile toprakların morfolojisi ve fiziko-kimyasal özellikleri farklılık gösterebilir (Sarı, 2015; Furquim ve ark., 2017; Owliaie ve ark., 2018; Gözükara, 2019; Gözükara ve ark., 2019a).

Geçmiş jeolojik devirlerde büyük ölçekli göl ve sığ deniz koşullarına sahip olmuş olan ve Türkiye'nin Güneybatısındaki "Göller Yöresi" olarak bilinen alanda pek çok aktif göl bulunmaktadır. Bu göllerden en önemlilerinden birisi de Burdur Gölü'dür. Ramsar kriterleri kapsamında altı metreyi geçmeyen kısımları "sulak alan" olarak tescil edilmiş olan Burdur Gölü'nün kimi yerleri, geçmiş jeolojik zaman süreçlerinde çeşitli düzeylerde çekilmek suretiyle karasal ortama kavuşmuştur (Atalay, 1977; Ataol, 2010; Tudryn ve ark., 2013). Bu gölün özellikle günümüzdeki çekilmesi, çok hızlı ve dramatik bir biçimde devam etmektedir (Gözükara ve ark., 2017; 2018; 2019a; 2019b). Farklı zaman dilimlerinde farklı mekanları sudan kurtulmuş olan bu lakustrin ana materyaller üzerinde çeşitli düzeylerde pedolojik değişim ve dönüşümlerin yaşanmış ve halen de yaşanıyor olması kaçınılmazdır. Günümüzde; çeşitli nedenlerle bir kısmı tarımsal üretimde kullanılmakta olan ve bir kısmında da halen hiçbir kullanım kararı ve uygulaması bulunmayan göl tabanları üzerinde yer almış olan toprakların oluşum ve gelişimlerinin hangi düzeylerde olduğu ve aynı zamanda bu toprakların zamansal ve mekansal farklııklarının nedenine dair sistematik ve bütüncül bir araştırma bulunmamaktadır.

Bu araştırma, günümüzde büyük bir hızla kurumakta olan Burdur Gölü'nün farklı zamanlarda farklı mekanlarında karasal ortama çıkmış olan eski göl tabanı arazileri üzerinde yer almış olan toprakların morfolojik, fiziksel ve kimyasal özelliklerinin tespit edilmesi ve bu toprakların pedolojik oluşum ve gelişim düzeylerindeki zamansal ve mekansal farklılıklarının belirlenmesi amacıyla planlanmıştır. 


\section{Materyal ve Metot}

\section{Materyal}

Araştırma, Türkiye'nin Göller Bölgesi'nde bulunan Burdur Gölü'nün geçmişten günümüze kadar süreçte karasal ortama çıkmış göl tabanı arazilerinde yürütülmüştür. Çalışma alanının Burdur göl çanağının güncel akaçlama noktalarının yaklaşık sınırı olan 1000 m yükseklik ile sınırlı tutulmuştur (Şekil 1). Çalışma alanı içerisinde yaklaşık $950 \mathrm{~m}$ 'den sonra göl tabanı arazilerine rastlanılmamış olması toprak profillerinin 846-946 m arasındaki yükseklik ile sınırlandırılmasına neden olmuştur. Çalışma alanı Isparta ve Burdur il Idari Sınırlarının içerisinde kalan 610.23 km²'lik alanı kapsamaktadır (Şekil 1a). Uzun yıllık (1975-2017) iklim verilerine göre çalışma alanının; ortalama sıcaklığı 13.34 ㅇ, ortalama toplam yağışı $419.01 \mathrm{~mm}$, ortalama toplam yüzey buharlaşması $1202.3 \mathrm{~mm}$ ve ortalama nisbi nemi \%58.07'dir (Gözükara, 2019).

Burdur Gölü'nün de içinde bulunduğu Burdur Havzası, tektonik olarak Fethiye-Burdur fay zonundan etkilenmiş tektonik granbendir. Burdur Gölü, Fethiye-Eğirdir Gölü arasında uzanan Güney Batı Anadolu Fay zonu içerisinde yer alır (Karaman, 1990). Fay zonu boyunca sol yönlü oblik normal fay hareketi etkin olmuştur. Göl günümüze kadar normal faylarla kademeli olarak çökmüştür. Fethiye-Burdur fay zonu, Isparta Açısı olarak bilinen otokton Toros Karbonat Ekseni'nin Antalya Körfezi kuzeyi ile Isparta çevresinde ters "V" şeklinde bükülmesi sonucu oluşmuştur (Bozcu vd. 2007). Yapısal kökenli bu deformasyon, bölgedeki tektonizma etkinliğinin en önemli göstergesidir. Günümüzde tektonik yönden aktif olan Isparta ve Burdur yöresi, eski jeolojik devirlerde de yapısal gerilmelerin etkisi altında kalmış ve değişik tür kıvrımlı, kırıklı, bindirmeli ve faylı yapılar kazanmıştır (Erol, 1980; Karaman, 1990; Kış ve ark., 1998). Kuvaterner devrinin Holosen döneminin başlaması ile iklim değişikliği ve havzadaki tektonik hareketlere bağlı çökmeler sonucunda göl seviyesinde düşüşlerin başladığı belirtilmiştir (Atalay, 1977; 2017; Tudryn ve ark., 2013). Araştırmacıların bu bulguları doğrultusunda çalışma alanı içerisinde yer alan eski göl tabanlarının oluşumu ve gelişiminin tamamının kuvaterner devirde gerçekleştiği tespit edilmiştir.

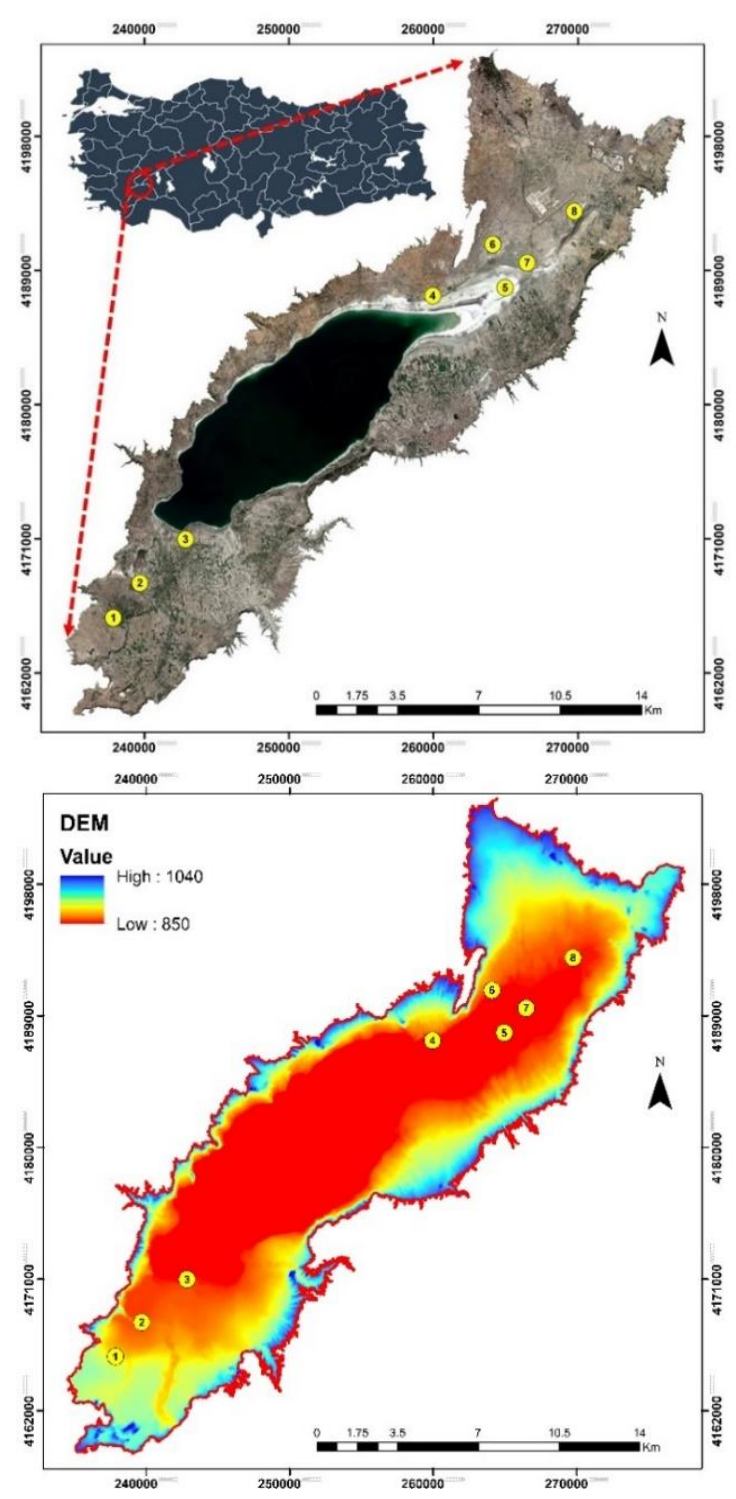

Şekil 1. Çalışma alanının coğrafik konumu (a) ve sayısal yükseklik modeli (b)

Figure 1. Geographical location of the study area (a) and DEM data (b)

Metot

\section{Büro çalışmaları}

Profil noktalarının yerlerinin tespit edilmesinde temel kartografik materyal olarak; Harita Genel Komutanlığı tarafından üretilen 1/25000 ölçekli Topografik Haritalar, Maden Tetkik Arama Genel Müdürlüğü tarafından üretilen $1 / 25000$ ve 1/100000 ölçekli Jeoloji Haritaları, Tapu Kadastro Genel Müdürlüğü (tarafından üretilen Stereo Ortofotolar (30 cm çözünürlüklü) ve Çizelge 1'de özellikleri gösterilen farklı yıllara ait uydu 
görüntüleri (Şekil 2) kullanılmıştır. Uydu görüntüleri üzerinde yapılan alansal hesaplamalarda ArcGIS 10.2 yazilımından faydalanılmıştır.

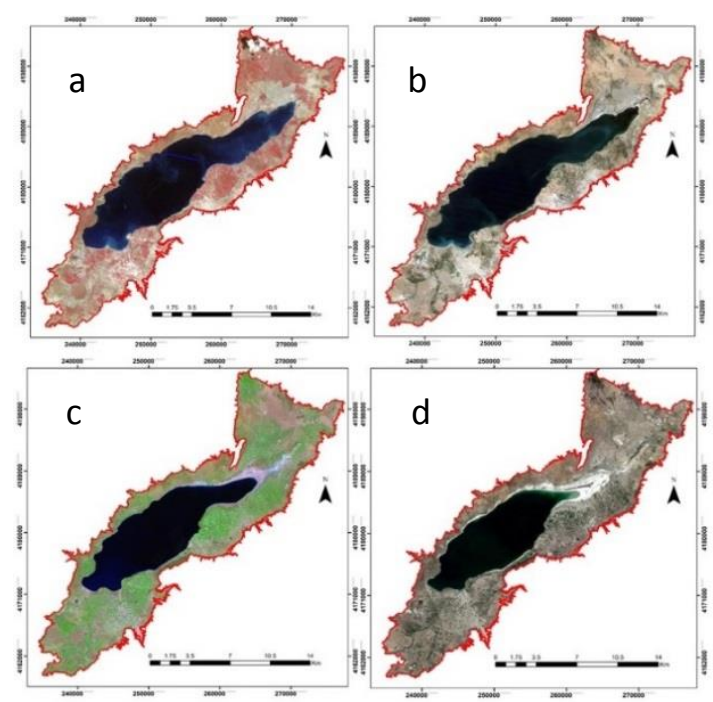

Şekil 2. Burdur Gölünün zamansal değişimi (a;1975, b;1987, c;2002, ve d; 2017)

Figure 2. Temporal change of Burdur Lake (a;1975, b;1987, c;2002, ve d; 2017)

Çizelge 2. Eski göl tabanı üzerinde gelişen profillerin özellikleri Table 2. Features of profiles devoleped on the old lake bottom

\begin{tabular}{|c|c|c|c|}
\hline $\begin{array}{l}\text { Profil No } \\
\text { Profile No }\end{array}$ & $\begin{array}{l}\text { Konum } \\
\text { Location }\end{array}$ & $\begin{array}{c}\text { Ana materyal } \\
\text { Parent Material }\end{array}$ & $\begin{array}{l}\text { Arazi Kullanımı } \\
\text { Land Use }\end{array}$ \\
\hline 1 & $37^{\circ} 36^{\prime} 03.44^{\prime \prime K} 30^{\circ} 01^{\prime} 50.55^{\prime \prime D}$ & Lakustrin & Bağ \\
\hline 2 & $37^{\circ} 37^{\prime} 21.47^{\prime \prime K} 30^{\circ} 03^{\prime} 01.41 " \mathrm{D}$ & Lakustrin & Çayır-Mera \\
\hline 3 & $37^{\circ} 39^{\prime} 00.06 " \mathrm{~K} 30^{\circ} 05^{\prime} 06.53 " \mathrm{D}$ & Lakustrin & Mera \\
\hline 4 & $37^{\circ} 48^{\prime} 08.799^{\prime K} 30^{\circ} 16^{\prime} 33.37^{\prime \prime D}$ & Lakustrin & Mera \\
\hline 5 & $37^{\circ} 48^{\prime} 23.73 " \mathrm{~K} 30^{\circ} 19^{\prime} 39.35^{\prime \prime D}$ & Lakustrin & - \\
\hline 6 & $37^{\circ} 50^{\prime} 01.70^{\prime \prime K} 30^{\circ} 19^{\prime} 09.46^{\prime \prime D}$ & Lakustrin & Kuru Tarım \\
\hline 7 & $37^{\circ} 49^{\prime} 23.60^{\prime \prime K} 30^{\circ} 20^{\prime} 48.63 " \mathrm{D}$ & Lakustrin & Mera \\
\hline 8 & $37^{\circ} 51^{\prime} 19.31 " \mathrm{~K} 30^{\circ} 22^{\prime} 57.21 " \mathrm{D}$ & Lakustrin & Kuru Tarım \\
\hline
\end{tabular}

\section{Laboratuvar çalışmaları}

Toprak örnekleri $2 \mathrm{~mm}$ 'lik elekten elenerek analizler için uygun hale getirilmiştir. Toprak örneklerinde, toprak bünyesi Bouyoucos (1955), organik madde Black (1965), pH ve EC Jackson (1967), kireç $\left(\mathrm{CaCO}_{3}\right)$ Scheibler Kalsimetresi ile (Soil survey manual, 1993), KDK ise $1 \mathrm{~N}$ amonyum asetat yöntemine göre belirlenmiştir (Soil Survey Laboratory Manual, 2004). Değişebilir katyonlar 1 $\mathrm{N}$ amonyum asetat yöntemine göre belirlenmiştir (Kacar 1995). Değişebilir sodyum yüzdesi (Bower 1959), Suda çözülebilir klor Johnson ve Ulrich (1959), suda çözülebilir sülfat Fox ve ark. (1964), suda çözülebilir karbonat ve bikarbonat karbonat Ayyıldız (1990) yöntemine göre yapılmıştır.
Çizelge 1. Uydu görüntülerinin özellikleri Table1. Features of satallite images

\begin{tabular}{ccc}
\hline No & $\begin{array}{c}\text { Tarih } \\
\text { Date }\end{array}$ & $\begin{array}{c}\text { Uydu ve Çözünürlük } \\
\text { Satellite and Resolution }\end{array}$ \\
\hline 1 & 16.06 .1975 & Landsat 2 (MSS)-60m \\
2 & 26.08 .1987 & Landsat 5 (TM)-30m \\
3 & 24.06 .2002 & Landsat 7 (ETM+)-15m \\
4 & 29.07 .2017 & Sentinel 2 (MSI)-10m \\
\hline
\end{tabular}

\section{Arazi çalışmaları}

$\mathrm{Bu}$ çalışma kapsamında eski göl tabanları üzerinde konumları ve özellikleri Çizelge 2'de gösterilen 8 adet toprak profili açılmış ve bu profillerde 50 farklı horizon tanımlanmıştır. Bu horzionların her birisi morfometrik-genetik yaklaşımla tanımlanmıştır (Şenol, 2015). Morfolojik tanımlamaları yapılmış olan her bir horizondan fiziksel ve kimyasal analizlerde kullanılmak amacıyla 50 adet toprak örneği alınmıştır.

\section{Araştırma Bulguları ve Tartışma}

Burdur Havzası'nın jeomorfolojik gelişiminde ve havzanın günümüzdeki görünümünü almasında Miyosen başlarında Burdur Havzası'nın bulunduğu alanda çökmeler ve kuvaternerde meydana gelen iklim değişimleri önemli rol oynamıştır (Atalay, 1977; 2017; Tudryn ve ark., 2013). Söz konusu bu jeolojik, jeomorfolojik ve ekolojik değişiklikler Burdur Gölü’nün su seviyesindeki değişimlerin ve aynı zamanda göl havzasındaki farklı fizyografik oluşumların da nedeni olmuştur. Aynı değişiklikler göl havzasındaki farklı fizyografyalarda yer alan topraklarda da çeşitli pedolojik değişimlerin yaşanmasına neden olmuştur. Bu alanda yapılan çalışmalar, Burdur Gölü'nün su seviyesinde gerek geçmiş jeolojik devirlerde ve gerekse yakın 
tarihlerde göl seviyesinde önemli azalmaların meydana gelmiş olduğunu göstermiştir. (Girgin ve ark., 2004; Şener ve Morova, 2011; Kahraman, 2013; Keskin, vd. 2015; Sarp ve Ozcelik, 2017; Gözükara ve ark., 2017, 2018; Gözükara, 2019; Gözükara ve ark., 2019a; 2019b). Özellikle son yıllarda (1975-2017) Burdur Gölü su seviyesinde ve hacminde ciddi bir azalmanın olduğu ve bu azalma neticesinde $80.91 \mathrm{~km}^{2}$ eski göl tabanı arazisinin karasal ortama çıktığı tespit edilmiştir. Aynı zamanda bu arazilerin üzerlerinde gelişen toprakların özelliklerinin bilinmediği ise açık bir gerçektir (Gözükara ve ark., 2017, 2018; 2019a; 2019b; Gözükara, 2019).

Eski göl tabanı üzerinde gelişen toprak profillerinin Burdur Gölü'nün merkezine göre konumları ile deniz seviyesine göre yükseklikleri değerlendirildiğinde; güney batıda $898 \mathrm{~m}$ yükseklikte $P 1,868 \mathrm{~m}$ yükseklikte $\mathrm{P} 2,856 \mathrm{~m}$ yükseklikte $P 3$, kuzey doğuda $846 \mathrm{~m}$ yükseklikte P5, 855 m yükseklikte P4, 852 m yükseklikte P7, $859 \mathrm{~m}$ yükseklikte P8 ve $860 \mathrm{~m}$ yükseklikte P6 profilleri yer almaktadır (Şekil 3). Eski göl tabanı üzerinde yaklaşık 845-898 $\mathrm{m}$ arasındaki yüksekliklerde pedogenetik olarak gelişim gösteren profillerin mekansal farklılıkları ve çevresel görüntüleri Şekil 4'de gösterilmiştir.

Kuvaterner döneminin ağırlıklı olarak holosen bölümünde çeşitli toprak oluşum faktörlerinin etkisiyle jeogenetik ve pedogetik olarak gelişimleri sürdüren $\mathrm{P} 1, \mathrm{P} 2, \mathrm{P} 3, \mathrm{P} 4, \mathrm{P} 5, \mathrm{P} 6, \mathrm{P} 7$ ve $\mathrm{P} 8$ profillerinin tamamı A-C horizon dizilimine sahiptir (Çizelge 3). Burdur Gölü'nün Güney Batı Sahilinde (GBS) yer alan P1, P2 ve P3 profillerinde yaş renk dağılımı yüzeydeki birkaç horizonda 10YR, alt horizonlarda ise $2.5 \mathrm{Y}$ olarak belirlenmiştir. Kuzey Doğu Sahilinde (KDS) yer alan $\mathrm{P} 4$ profilinin $\mathrm{A} 1$ ve $2 \mathrm{~A}$ horizonlarında yaş renk 2.5Y, alt horizonlarda 10YR, P5 profilinin A1

horizonunda yaş renk $2.5 \mathrm{Y}, 2 \mathrm{C}$ ve $3 \mathrm{C}$ horizonlarında ise Gley 1 olarak belirlenmiştir. P7 ve $\mathrm{P} 8$ profillerindin tamamında yaş renk $2.5 \mathrm{Y}$ olarak tespit edilirken, $\mathrm{P} 6$ profilinin $\mathrm{Ap}, \mathrm{A} 2$ ve $2 \mathrm{C}$ horizonlarında yaş renk $2.5 \mathrm{Y}$, diğer horizonlarda ise $5 Y$ olarak tespit edilmiştir. Özellikle P5 profilinin $2 \mathrm{C}$ ve $3 \mathrm{C}$ horizonlarında yaş renk çalışma alanı içerisindeki profillerdeki hiçbir horizon ile benzerlik göstermemektedir. Özellikle GBS'de bulunan P1, P2 ve P3 profillerinin yüzey horizonlarındaki yaş rengin 10YR düzeyinde kırmızılaşmış olması da söz konusu bu topraklardaki pedolojik işlemlerin azımsanamayacak derecede yüksek olduğunu göstermektedir (Çizelge 3). GBS' de bulunan P1, P2 ve P3 profillerinin genellikle yüzey horizonlarında kuvvetli orta yarı köşeli blok, orta orta yarı köşeli blok ve orta orta granüler strüktür tespit edilirken C horizonlarının tamamında masif strüktür tespit edilmiştir. Burdur Gölü'nün güncel göl sınırlarına yaklaştıkça GBS'de bulunan P1, P2 ve P3 profillerinde strüktürel oluşum azalmaktadır. GBS' de Burdur Gölü'ne en yakın olan P3 profilinde yüzeyden itibaren yaklaşık $15-20 \mathrm{~cm}$ strüktür oluşumu, P2 profilinde $30-35 \mathrm{~cm}$ strüktür oluşumu ve göle en uzak mesafede olan P3 profilinde ise $40-45 \mathrm{~cm}$ strüktür oluşumu tespit edilmiştir (Çizelge 3). Bu bulgular "Burdur Gölü'ne yaklaştıkça profillerdeki strüktürel oluşum azalmaktadır" şeklindeki tespitimizi desteklemektedir. Strüktür, KDS'de bulunan P4, P6, P7 ve P8 profillerinin yüzey horizonlarında zayıf küçük granüler, zayıf küçük yarı köşeli blok, kuvvetli orta yarı köşeli blok ve orta orta yarı köşeli blok olarak tespit edilmiştir. P5 profilinin yüzey horizonunda ise srüktür masif olarak tespit edilmiştir. KDS'de bulunan P4, P5, P6, P7 ve P8 profillerinin $C$ horizonlarının tamamında masif strüktür tespit edilmiştir (Çizelge 3). KDS'de bulunan P5, P7 ve P8 profillerinde Burdur Gölü'ne yaklaştıkça profillerdeki strüktürel gelişim azalmaktadır. KDS'de Burdur Gölü'ne en yakın olan P5 profilinde yüzeyde herhangi bir strüktür gelişiminin olmaması, P7 profilinde yaklaşık $10 \mathrm{~cm}$ strüktür gelişimi ve göle en uzak mesafede olan P8 profilinde ise $20-25 \mathrm{~cm}$ strüktür gelişimi tespit edilmiştir. Bu bulgular “KDS'de Burdur Gölü'ne yaklaştıkça profillerdeki strüktürel gelişim azalmaktadır" şeklindeki tespitimizi desteklemektedir. GBS'deki profillerin KDS'de bulunan profillere göre yüzeyden itibaren daha fazla strüktür oluşumu tespit edilmiştir. GBS ve KDS bulunan profiller arasında değişebilir $\mathrm{Na}$ 
içeriğinin fazla olduğu P2, P3, P5, P6, P7 ve P8 profillerinde nemli kıvamlar genellikle çok sıkı ve sıkı olarak belirlenmiştir. Fakat $\mathrm{Na}^{+\prime}$ un hidratasyon çapının yüksek olması ve strüktürel üniteler arasındaki bağların zayıf olması sonucunda özellikle nemli kıvamların dağılgan olması bekleniyordu. Profillerin aşırı kireç içeriğin ve değişebilir $\mathrm{Ca}^{++}+\mathrm{Mg}^{++}$katyonlarının fazla olması $\mathrm{Na}^{+\prime}$ un disperse edici ve/veya strüktür bozucu etkilerini dengelemiş hatta kısmen de olsa $\mathrm{Ca}^{++\prime} \mathrm{un}$ koagülasyon özelliğine bağı olarak toprak taneciklerini bir arada tutmada etkili olduğu gözükmektedir.

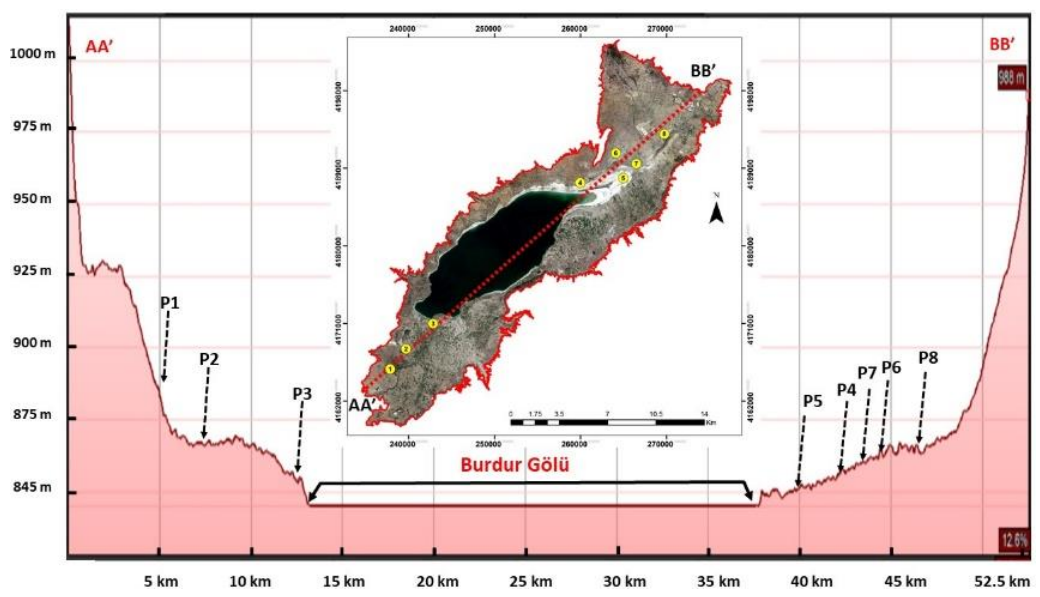

Şekil 3. Profillerin yükseklik dağılımı

Figure 3. Altitude distribution of profiles
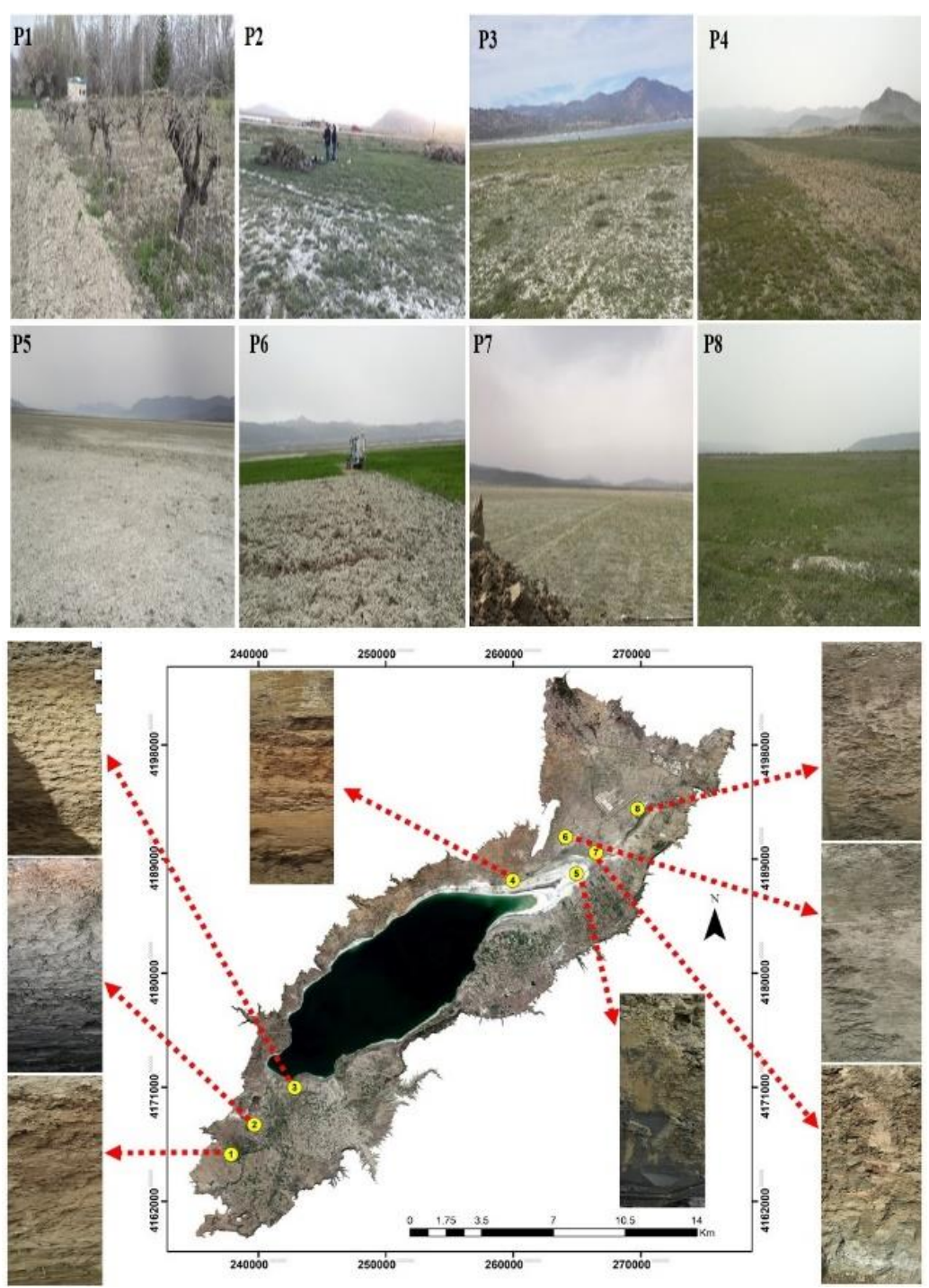

Şekil 4. Profillerin çevresel ve horizon görünümü

Figure 4. Environmental and horizon view of profiles 
GBS'de yeralan P2 profili Kumluca, Yarıköy ve Yazıköylerinin çevrelediği bir alanda çevresindeki diğer toprak profillerine (P1 ve P3) göre lokal tektonik çöküntü alanında bulunmaktadır. Topoğrafyadaki bu çukurluk, topografyaya gelen yüzey sularının taşıyarak getirdiği en ince materyallerin (kil) bu toprak profilin yayılım gösterdiği alanlarda birikmesine neden olmaktadır. Bu topoğrafik özelliğe bağlı olarak profilin 4C horizonu (\%22 kil) hariç diğer horizonlar yoğun kil içeriğine sahiptir. Aynı zamanda yoğun kil içeriğine ve dönemlik yükselme eğiliminde olan taban suyuna bağlı olarak profilde $7 \mathrm{~cm}$ 'den itibaren alt horizonlara doğru artan oranda pas lekeleri gözlemlenmiştir. Aynı zamanda yoğun kil içeriğine bağlı olarak $A 1$, $3 \mathrm{C}$ ve $5 \mathrm{C}$ horizonlarında yoğun kayma yüzeyleri tespit edilmiştir (Çizelge 3 ).

P1 profili GBS'de bulunan diğer profillere göre en düşük kil içeriği ile kumlu killi tın, killi tın ve tın tekstüre sahiptir. Güncel gölün kıyı çizgisine yakın bir mesafede (Şekil 4) yayılım gösteren P3 profilinde ise sekiz farklı litolojik kesilme belirlenmiştir. Neredeyse her litolojik kesilmede farklı havzalardan farklı akarsu debilerine bağlı olarak değişen miktarlarda kum/silt/kil malzemeleri göl tabanına depolanmıştır. P3 profilinde toprakların birbirinden çok farklı tekstür sınıflarına bağlı olarak morfolojik, fiziksel ve kimyasal özelliklerinde ciddi farklılıkların bulunduğu görülmektedir. Örneğin; yaklaşık 170$180 \mathrm{~cm}$ derinliğinde açılarak incelenmiş olan bu profilde $A 1,2 C, 3 C, 4 C, 5 C, 6 C, 7 C$ ve $8 C$ şeklinde bir horizon dağılımının bulunduğu ve her bir horizonun tekstür sınıfı tınlı kum (LS)'dan siltli kil'e (SiC) kadar değişiklik göstermektedir (Çizelge 3). P3 profilinde ise yüzeye yakın $2 \mathrm{C}$ horizonunda (17$38 \mathrm{~cm}$ ) orta yoğun pas lekeleri, azalan kil miktarı ile birlikte $3 \mathrm{C}, 4 \mathrm{C}$ ve $5 \mathrm{C}$ horizonlarında herhangi pas lekesi gözlemlenmezken $6 C, 7 C$ ve $8 C$ horizonlarında ise artış gösteren kil miktarına bağlı olarak çok yoğun pas lekeleri gözlemlenmiştir. Aynı zamanda kireç, organik madde, KDK, değişebilir katyon ve diğer fiziko- kimyasal özelliklerdeki değişimin de son derece düzensiz olduğu görülmektedir (Çizelge 3). Çalışma alanının özellikle KDS bölümünde kuzey ve kuzeydoğu istikametinden Burdur gölüne doğru akmakta olan birkaç mevsimlik derenin eski jeolojik süreçlerdeki faaliyetleri kapsamında farklı mekanlardan getirmiş oldukları materyaller bu alanda birikmiştir. Bununla birlikte KDS'de bulunan P4, P5, P6, P7 ve P8 profillerinin yayılım gösterdiği alanlar söz konusu derelerin materyal depolama güzergahlarının (boylamasına dereceleme alanlarının) neredeyse son kısımlarında olması ve hatta yakın geçmişe kadar söz konusu bu alanların göl suları altında olmaları nedeniyle bu profillerin tekstürleri çoğunlukla ağır kildir. KDS'de bulunan profiller arasında en fazla kil içeriği \%56.23-83.09 değiş̧im aralığı ile P6'da tespit edilmiştir (Çizelge 3). KDS'de bulunan profiller arasında göle en yakın mesafede bulunan P5 profili diğer profillere göre kuzey ve kuzeydoğu istikametinden Burdur Gölü'ne doğru akmakta olan birkaç mevsimlik derenin eski jeolojik süreçlerdeki faaliyetleri kapsamında farklı mekanlardan getirmiş oldukları en ince materyallerin taşınarak biriktirildiği konumda bulunmaktadır (Şekil 4). Profilin tamamındaki yoğun kil ve dönemlik taban suyu sonucunda $A 1$ horizonunda zayıf pas lekeleri, $2 C$ ve $3 C$ horizonlarında ise yoğun gleyizasyon izleri gözlemlenmiştir. Burdur Gölü'nden uzaklaştıkça P7 profilinin 2C horizonunda yoğun olan pas lekeleri, alt horizonlara doğru ise çok yoğun pas lekeleri tespit edilmiştir. Göle en uzak mesafede bulunan P8 profilinde ise $3 \mathrm{C}$ horizonundan (79$106 \mathrm{~cm}$ ) itibaren artan şiddette pas lekeleri gözlemlenmiştir. P4 profilinin sadece $4 C, 5 C$ ve $6 C$ horizonlarında zayıf pas lekeleri gözlemlenirken, P6 profilinde herhangi bir pas lekesi tespit edilmemiştir. Göründüğü üzere $K D S$ ve $G^{\prime} S^{\prime}$ de bulunan profillerde güncel göl sınırından uzaklaştıkça kil içeriğine ve taban suyunun dönemlik hareketlerine bağlı olarak pas lekeleri azalmaktadır. 
Çizelge 3. Profillerin bazı fiziksel ve kimyasal özellikleri

Table 3. Some physical and chemical properties of profiles

\begin{tabular}{|c|c|c|c|c|c|c|c|c|c|c|c|}
\hline $\begin{array}{l}\text { Profil } \\
\text { Profile }\end{array}$ & $\begin{array}{l}\text { Horizon } \\
\text { Horizon }\end{array}$ & $\begin{array}{l}\text { Derinlik } \\
\text { Depth } \\
(\mathrm{cm})\end{array}$ & $\begin{array}{l}\text { Renk } \\
\text { Color } \\
\text { (Yaş) }\end{array}$ & $\begin{array}{l}\text { Strüktür } \\
\text { Structure }\end{array}$ & $\begin{array}{l}\text { Özel Görünüm } \\
\text { Special feaures }\end{array}$ & $\begin{array}{l}\text { Kireç } \\
\text { Lime } \\
(\%)\end{array}$ & $\begin{array}{l}\text { Organik } \\
\text { Madde } \\
\text { Organic } \\
\text { Matter } \\
(\%)\end{array}$ & $\begin{array}{l}\text { Kum } \\
\text { Sand } \\
(\%)\end{array}$ & $\begin{array}{l}\text { Silt } \\
\text { Loam } \\
(\%)\end{array}$ & $\begin{array}{l}\text { Kil } \\
\text { Clay } \\
(\%)\end{array}$ & $\begin{array}{l}\text { Tekstür } \\
\text { Texture }\end{array}$ \\
\hline \multirow{5}{*}{ P1 } & Ap & $0-24$ & 10YR 5/2 & OOYKB & SSK & 25.63 & 1.12 & 54.54 & 22.50 & 22.96 & $\mathrm{SCL}$ \\
\hline & $2 A$ & $24-45$ & 10YR 6/3 & ÇKOKB & SSK & 27.88 & 0.76 & 50.90 & 23.14 & 25.96 & $\mathrm{SCL}$ \\
\hline & $3 C$ & $45-72$ & $2.5 Y 7 / 3$ & Masif & SSK & 34.71 & 0.64 & 41.05 & 31.14 & 27.81 & $\mathrm{CL}$ \\
\hline & $4 C$ & $72-113$ & $2.5 Y 8 / 2$ & Masif & SSK & 39.69 & 0.60 & 20.98 & 50.14 & 28.88 & $\mathrm{CL}$ \\
\hline & $5 \mathrm{C}$ & $133+$ & $2.5 Y 7 / 2$ & Masif & - & 30.37 & 0.46 & 38.83 & 43.22 & 17.95 & $\mathrm{~L}$ \\
\hline \multirow{7}{*}{ P2 } & $\mathrm{A} 1$ & $0-7$ & 10YR $6 / 3$ & OOG & SSK, AYKY & 34.15 & 1.37 & 6.90 & 45.14 & 47.96 & $\mathrm{SiC}$ \\
\hline & $A C$ & $7-33$ & 10YR 5/2 & KOYKB & ÇZPL, AYKY & 30.29 & 0.74 & 1.05 & 33.36 & 65.59 & $\mathrm{C}$ \\
\hline & $2 \mathrm{C} 1$ & $33-59$ & $2.5 Y 5 / 2$ & Masif & ÇZPL, AYKY & 31.34 & 0.59 & 0.98 & 32.29 & 66.73 & $\mathrm{C}$ \\
\hline & $2 C 2$ & $59-85$ & $2.5 Y 4 / 2$ & Masif & OYPL, YKY & 32.54 & 0.45 & 0.98 & 31.36 & 67.66 & $\mathrm{C}$ \\
\hline & $2 C 3 g$ & $85-120$ & $2.5 Y 5 / 2$ & Masif & OYPL, GI, YKY & 32.14 & 0.49 & 1.05 & 30.22 & 68.73 & $\mathrm{C}$ \\
\hline & $3 \mathrm{Cg}$ & $120-130$ & $2.5 Y 5 / 2$ & Masif & OYPL, GI, YKY & 36.84 & 0.29 & 31.05 & 46.22 & 22.73 & L \\
\hline & $4 \mathrm{Cg}$ & $130+$ & $2.5 Y 4 / 3$ & Masif & ÇYPL, GI, YKY & 32.46 & 0.33 & 1.05 & 38.22 & 60.73 & $\mathrm{C}$ \\
\hline \multirow{8}{*}{ P3 } & $\mathrm{A} 1$ & $0-17$ & 10YR 5/3 & ZOYKB & YSK & 34.84 & 1.45 & 31.77 & 37.78 & 30.45 & $\mathrm{CL}$ \\
\hline & $2 \mathrm{C}$ & $17-38$ & 10YR 6/3 & Masif & YSK, OYPL & 37.75 & 0.81 & 41.13 & 37.49 & 21.38 & $\mathrm{~L}$ \\
\hline & $3 C$ & $38-59$ & 10YR $6 / 2$ & Masif & - & 33.71 & 0.94 & 12.84 & 57.70 & 29.46 & $\mathrm{SiCL}$ \\
\hline & $4 C$ & $59-86$ & $2.5 Y 6 / 3$ & Masif & - & 37.34 & 1.04 & 49.06 & 38.49 & 12.45 & $\mathrm{~L}$ \\
\hline & $5 C$ & $86-96$ & $2.5 Y 6 / 4$ & Masif & - & 44.13 & 1.11 & 82.62 & 9.78 & 7.60 & LS \\
\hline & $6 C$ & $96-113$ & $2.5 Y 6 / 3$ & Masif & ÇYPL & 31.44 & 1.03 & 5.77 & 40.56 & 53.67 & $\mathrm{SiC}$ \\
\hline & 7C & $113-140$ & $2.5 Y 6 / 3$ & Masif & ÇYPL & 30.47 & 1.10 & 15.34 & 46.92 & 37.74 & $\mathrm{SiCL}$ \\
\hline & $8 C$ & $140+$ & $2.5 Y 6 / 2$ & Masif & ÇYPL & 25.78 & 1.05 & 0.62 & 40.92 & 58.46 & $\mathrm{SiC}$ \\
\hline \multirow{7}{*}{ P4 } & A1 & $0-14$ & $2.5 Y 6 / 3$ & ZKG & YSK & 31.81 & 3.45 & 14.34 & 49.64 & 36.02 & $\mathrm{SiCL}$ \\
\hline & $2 \mathrm{~A}$ & $14-34$ & $2.5 Y 5 / 2$ & OOYKB & SSK & 27.99 & 3.41 & 10.06 & 38.93 & 51.01 & C \\
\hline & $3 A$ & $34-58$ & 10YR $4 / 4$ & OOYKB & SSK & 22.96 & 2.53 & 4.06 & 49.00 & 46.94 & $\mathrm{SiC}$ \\
\hline & $3 C$ & $58-76$ & 5YR 5/4 & Masif & $2 \mathrm{~cm}$ Kum Bandı & 17.93 & 1.43 & 8.98 & 45.78 & 45.23 & $\mathrm{SiC}$ \\
\hline & $4 C$ & $76-84$ & 10YR $6 / 3$ & Masif & $\mathrm{ZPL}$ & 25.32 & 0.18 & 56.06 & 26.93 & 17.01 & $\mathrm{SL}$ \\
\hline & $5 C$ & $84-97$ & 10YR $6 / 3$ & Masif & $\mathrm{ZPL}$ & 25.07 & 0.53 & 35.06 & 35.64 & 29.30 & $\mathrm{CL}$ \\
\hline & $6 \mathrm{~A}$ & $97+$ & 10YR $4 / 1$ & Masif & ZPL, OMP & 15.01 & 3.08 & 10.13 & 57.78 & 32.09 & $\mathrm{SiCL}$ \\
\hline
\end{tabular}




\begin{tabular}{|c|c|c|c|c|c|c|c|c|c|c|c|}
\hline $\begin{array}{l}\text { Profil } \\
\text { Profile }\end{array}$ & $\begin{array}{l}\text { Horizon } \\
\text { Horizon }\end{array}$ & $\begin{array}{l}\text { Derinlik } \\
\text { Depth } \\
(\mathrm{cm})\end{array}$ & $\begin{array}{l}\text { Renk } \\
\text { Color } \\
\text { (Yaş) }\end{array}$ & $\begin{array}{l}\text { Strüktür } \\
\text { Structure }\end{array}$ & $\begin{array}{l}\text { Özel Görünüm } \\
\text { Special feaures }\end{array}$ & $\begin{array}{l}\text { Kireç } \\
\text { Lime } \\
(\%)\end{array}$ & $\begin{array}{l}\text { Organik } \\
\text { Madde } \\
\text { Organic } \\
\text { Matter } \\
(\%)\end{array}$ & $\begin{array}{l}\text { Kum } \\
\text { Sand } \\
(\%)\end{array}$ & $\begin{array}{l}\text { Silt } \\
\text { Loam } \\
(\%)\end{array}$ & $\begin{array}{l}\text { Kil } \\
\text { Clay } \\
(\%)\end{array}$ & $\begin{array}{l}\text { Tekstür } \\
\text { Texture }\end{array}$ \\
\hline \multirow{3}{*}{ P5 } & A1g & $0-10$ & $2.5 Y 6 / 3$ & Masif & ZPL, YG & 19.96 & 2.59 & 1.13 & 72.93 & 25.94 & SiL \\
\hline & $2 \mathrm{Cg}$ & $10-25$ & Gley $12.5 / \mathrm{N}$ & Masif & YG & 21.99 & 3.56 & 6.27 & 85.78 & 7.95 & $\mathrm{Si}$ \\
\hline & $3 \mathrm{Cg}$ & $25+$ & Gley $12.5 / \mathrm{N}$ & Masif & YG & 18.82 & 2.76 & 5.98 & 70.00 & 24.02 & SiL \\
\hline \multirow{7}{*}{ P6 } & $A p$ & $0-15$ & $2.5 Y 6 / 2$ & KOYKB & YSK & 39.43 & 1.86 & 20.06 & 23.71 & 56.23 & $\mathrm{C}$ \\
\hline & $\mathrm{A} 2$ & $15-35$ & $2.5 Y 7 / 2$ & OOYKB & YSK & 39.03 & 1.03 & 14.06 & 21.93 & 64.01 & C \\
\hline & $2 \mathrm{C}$ & $35-60$ & $2.5 Y 7 / 2$ & Masif & - & 30.59 & 0.87 & 2.06 & 14.86 & 83.08 & C \\
\hline & $3 C 1$ & $60-99$ & $5 Y 7 / 2$ & Masif & $1 \mathrm{~cm}$ kum bandı & 48.20 & 0.70 & 17.20 & 18.64 & 64.16 & $\mathrm{C}$ \\
\hline & $3 C 2$ & $90-110$ & $5 Y 7 / 1$ & Masif & - & 44.14 & 0.49 & 2.98 & 18.86 & 78.16 & $\mathrm{C}$ \\
\hline & $4 C 1$ & $110-130$ & $5 Y 8 / 2$ & Masif & AYKB & 39.35 & 0.49 & 12.20 & 26.57 & 61.23 & $\mathrm{C}$ \\
\hline & $4 C 2$ & $130+$ & $5 Y 8 / 1$ & Masif & AYKB & 37.16 & 0.32 & 5.27 & 25.42 & 69.31 & $\mathrm{C}$ \\
\hline \multirow{6}{*}{ P7 } & A1 & $0-10$ & $2.5 Y 5 / 2$ & ZKYKB & ÇYSK & 12.06 & 4.40 & 4.98 & 83.72 & 11.30 & $\mathrm{Si}$ \\
\hline & $2 C$ & $10-21$ & $2.5 Y 5 / 3$ & Masif & YPL, YSK & 14.48 & 2.80 & 0.98 & 64.79 & 34.23 & $\mathrm{SiCL}$ \\
\hline & $3 C$ & $21-46$ & $2.5 Y 6 / 2$ & Masif & ÇYPL, YSK & 12.15 & 0.51 & 2.90 & 56.86 & 40.24 & $\mathrm{SiC}$ \\
\hline & $4 C$ & $46-88$ & $2.5 Y 6 / 2$ & Masif & ÇYPL, SSK & 16.17 & 0.48 & 0.19 & 39.50 & 60.31 & $\mathrm{C}$ \\
\hline & $5 C$ & $88-104$ & $2.5 Y 7 / 1$ & Masif & ÇYPL, GI & 27.35 & 0.46 & 0.41 & 22.72 & 76.87 & C \\
\hline & $6 \mathrm{Ckg}$ & $104+$ & $2.5 Y 8 / 1$ & Masif & ÇYPL, Gi & 43.19 & 0.38 & 1.48 & 67.00 & 31.52 & $\mathrm{SiCL}$ \\
\hline \multirow{7}{*}{ P8 } & $\mathrm{A} 1$ & $0-22$ & $2.5 Y 5 / 3$ & OOYKB & YSK & 28.94 & 3.60 & 3.06 & 39.50 & 57.44 & $C$ \\
\hline & $A C$ & $22-48$ & $2.5 Y 5 / 4$ & Masif & SSK, SKTB & 27.97 & 2.25 & 2.34 & 48.59 & 49.07 & sic \\
\hline & $\mathrm{C}$ & $48-79$ & $2.5 Y 6 / 3$ & Masif & SSK, YKTB & 30.39 & 1.93 & 0.98 & 42.52 & 56.50 & sic \\
\hline & $2 \mathrm{~A}$ & $79-106$ & $2.5 Y 6 / 2$ & ZOYKB & YKTB, ZPL & 31.28 & 3.88 & 0.77 & 24.64 & 74.59 & $\mathrm{C}$ \\
\hline & $2 \mathrm{C} 1 \mathrm{~g}$ & $106-122$ & $2.5 Y 7 / 2$ & Masif & ÇYPL, Gi & 31.52 & 2.76 & 0.63 & 37.78 & 61.59 & $C$ \\
\hline & $2 \mathrm{C} 2 \mathrm{~g}$ & $122-156$ & $2.5 Y 7 / 2$ & Masif & ÇYPL, Gi & 31.36 & 1.26 & 1.13 & 24.21 & 74.66 & C \\
\hline & $3 \mathrm{Cg}$ & $156+$ & $2.5 Y 7 / 2$ & Masif & ÇYPL, Gi & 38.96 & 2.36 & 15.49 & 47.85 & 36.66 & SiCL \\
\hline \multicolumn{12}{|c|}{$\begin{array}{l}\text { *Strüktür; ÇKOKB: Çok Kuvvetli Orta Köşeli Blok, KOYKB: Kuvvetli Orta Yarı Köşeli Blok, OOYKB: Orta orta yarı köşeli blok, ZOYKB: Zayıf Orta Yarı Köşeli Blok, ZKYKB: Zayıf Küçük Yarı } \\
\text { Köşeli Blok, ZKYKB: Zayıf Küçük Yarı Köşeli Blok } \\
\text { **özel Görünümler; SSK: Seyrek Saçak Kök, YSK: Yaygın Saçak Kök, ÇYSK: Çok Yoğun Saçak Kök, ÇZPL: Çok Zayıf Pas Lekesi, ZPL: Zayıf Pas Lekesi, OYPL: Orta Yoğun Pas Lekesi, YPL: } \\
\text { Yoğun Pas Lekesi, ÇYPL: Çok Yoğun Pas Lekeleri, Gi: Gleyizasyon İleri, YG: Yoğun Gleyizasyon, AYKB: Az yoğun Kireç Benekleri, SKTB: Seyrek Kapilar Tuz Birikimi, YKTB: Yoğun Kapilar Tuz } \\
\text { Birikimi, OMP: Organik Madde Parçaları, AYKY: Az Yoğun Kayma Yüzeyleri }\end{array}$} \\
\hline
\end{tabular}


Çizelge 4. Profillerin bazı kimyasal özellikleri

Çizelge 4. Some chemical properties of profiles

\begin{tabular}{|c|c|c|c|c|c|c|c|c|c|c|c|c|c|}
\hline \multirow[t]{2}{*}{$\begin{array}{l}\text { Profil } \\
\text { Profile }\end{array}$} & \multirow[t]{2}{*}{$\begin{array}{l}\text { Horizon } \\
\text { Horizon }\end{array}$} & \multirow[t]{2}{*}{$\begin{array}{l}\text { Derinlik } \\
\text { Depth } \\
(\mathrm{cm})\end{array}$} & \multirow[t]{2}{*}{$\mathrm{pH}$} & \multirow[t]{2}{*}{$\begin{array}{l}\mathrm{EC} \\
\left(\mathrm{dS} \mathrm{m}^{-1}\right)\end{array}$} & \multicolumn{4}{|c|}{$\begin{array}{l}\text { Suda Çözünebilir Anyonlar } \\
\text { Water Soluble Anions } \\
\left(\mathrm{me} \mathrm{l}^{-1}\right)\end{array}$} & \multicolumn{3}{|c|}{$\begin{array}{l}\text { Değişebilir Katyonlar } \\
\text { Exchangable Cations } \\
\left(\text { me } 100 \mathrm{~g}^{-1}\right)\end{array}$} & \multirow[t]{2}{*}{$\begin{array}{l}\text { KDK } \\
\left(\text { me } 100 g^{-1}\right)\end{array}$} & \multirow[t]{2}{*}{ ESP } \\
\hline & & & & & $\mathrm{CO}_{3}{ }^{-2}$ & $\mathrm{HCO}_{3}{ }^{-}$ & $\mathrm{Cl}^{-}$ & $\mathrm{SO}_{4}^{-2}$ & $\mathrm{Na}^{+}$ & $\mathrm{K}^{+}$ & $\mathrm{Ca}^{++}+\mathrm{Mg}^{++}$ & & \\
\hline \multirow{5}{*}{ P1 } & Ap & $0-24$ & 7.73 & 0.39 & 0.48 & 1.38 & 1.40 & 0.45 & 0.15 & 0.68 & 16.32 & 17.16 & 0.90 \\
\hline & $2 \mathrm{~A}$ & $24-45$ & 7.96 & 0.30 & 1.00 & 3.66 & 1.80 & 1.42 & 0.14 & 0.76 & 16.46 & 17.36 & 0.80 \\
\hline & $3 C$ & $45-72$ & 7.98 & 0.31 & 0.68 & 1.26 & 2.50 & 0.99 & 0.30 & 0.10 & 18.76 & 19.16 & 1.55 \\
\hline & $4 C$ & $72-113$ & 8.15 & 0.33 & 0.76 & 1.58 & 2.30 & 0.77 & 0.59 & 0.06 & 19.78 & 20.43 & 2.86 \\
\hline & $5 C$ & $133+$ & 8.33 & 0.35 & 0.64 & 1.38 & 2.20 & 0.34 & 0.94 & 0.07 & 19.76 & 20.77 & 4.54 \\
\hline \multirow{7}{*}{ P2 } & $\mathrm{A} 1$ & $0-7$ & 8.80 & 2.29 & 0.92 & 3.44 & 8.00 & 10.44 & 11.69 & 0.37 & 13.14 & 25.20 & 46.38 \\
\hline & $A C$ & $7-33$ & 9.09 & 2.74 & 0.60 & 4.90 & 13.10 & 5.82 & 20.41 & 0.40 & 11.39 & 32.21 & 63.37 \\
\hline & $2 \mathrm{C} 1$ & $33-59$ & 9.15 & 3.72 & 1.44 & 4.42 & 15.00 & 22.60 & 25.93 & 0.34 & 10.07 & 36.33 & 71.36 \\
\hline & $2 \mathrm{C} 2$ & $59-85$ & 9.34 & 2.64 & 2.60 & 5.10 & 9.60 & 8.51 & 21.82 & 0.31 & 9.23 & 31.37 & 69.57 \\
\hline & $2 C 3 g$ & $85-120$ & 9.44 & 1.55 & 2.96 & 6.82 & 6.40 & 3.77 & 20.03 & 0.33 & 9.33 & 29.68 & 67.48 \\
\hline & $3 \mathrm{Cg}$ & $120-130$ & 9.43 & 1.29 & 2.56 & 6.32 & 4.50 & 2.64 & 9.24 & 0.13 & 9.12 & 18.50 & 49.97 \\
\hline & $4 \mathrm{Cg}$ & $130+$ & 9.40 & 1.34 & 1.88 & 6.34 & 4.20 & 2.77 & 17.00 & 0.26 & 9.19 & 26.46 & 64.26 \\
\hline \multirow{8}{*}{ P3 } & $\mathrm{A} 1$ & $0-17$ & 8.11 & 0.29 & 0.20 & 1.98 & 1.10 & 1.02 & 0.53 & 0.30 & 17.63 & 18.46 & 2.88 \\
\hline & $2 C$ & $17-38$ & 9.23 & 0.81 & 1.36 & 7.26 & 4.80 & 2.57 & 5.27 & 0.23 & 12.52 & 18.02 & 29.25 \\
\hline & $3 C$ & $38-59$ & 9.45 & 1.11 & 1.80 & 8.68 & 2.80 & 1.61 & 10.49 & 0.26 & 11.07 & 21.83 & 48.06 \\
\hline & $4 C$ & $59-86$ & 9.53 & 0.88 & 1.08 & 5.56 & 2.50 & 1.43 & 5.59 & 0.14 & 10.10 & 15.83 & 35.30 \\
\hline & $5 C$ & $86-96$ & 9.29 & 0.71 & 0.72 & 3.26 & 3.50 & 1.93 & 2.95 & 0.10 & 10.64 & 13.69 & 21.55 \\
\hline & $6 C$ & $96-113$ & 8.95 & 2.18 & 1.12 & 4.16 & 9.60 & 5.74 & 12.62 & 0.35 & 14.62 & 27.59 & 45.75 \\
\hline & $7 C$ & $113-140$ & 8.99 & 1.87 & 1.16 & 3.98 & 9.70 & 5.24 & 11.63 & 0.27 & 12.74 & 24.64 & 47.21 \\
\hline & $8 C$ & $140+$ & 9.08 & 0.94 & 1.40 & 5.22 & 14.30 & 5.65 & 17.60 & 0.38 & 13.22 & 31.20 & 56.40 \\
\hline \multirow{7}{*}{ P4 } & $\mathrm{A} 1$ & $0-14$ & 8.48 & 0.48 & 0.72 & 2.78 & 1.70 & 0.46 & 0.33 & 0.47 & 12.96 & 13.75 & 2.36 \\
\hline & $2 \mathrm{~A}$ & $14-34$ & 8.50 & 0.51 & 0.60 & 2.74 & 2.10 & 1.70 & 0.48 & 0.68 & 16.66 & 17.82 & 2.70 \\
\hline & $3 A$ & $34-58$ & 8.29 & 2.23 & 0.48 & 1.58 & 5.80 & 20.01 & 5.34 & 0.86 & 16.46 & 22.67 & 23.57 \\
\hline & $3 C$ & $58-76$ & 8.02 & 8.88 & 0.12 & 1.56 & 21.50 & 80.54 & 19.66 & 0.74 & 19.73 & 40.13 & 48.98 \\
\hline & $4 C$ & $76-84$ & 8.24 & 3.90 & 0.12 & 0.56 & 10.80 & 29.44 & 7.78 & 0.23 & 13.15 & 21.17 & 36.75 \\
\hline & $5 C$ & $84-97$ & 7.97 & 5.97 & 0.12 & 1.42 & 16.50 & 44.74 & 12.41 & 0.37 & 16.23 & 29.01 & 42.78 \\
\hline & $6 \mathrm{~A}$ & $97+$ & 7.57 & 9.78 & 0.12 & 1.16 & 24.40 & 73.01 & 17.82 & 0.72 & 36.83 & 55.37 & 32.19 \\
\hline
\end{tabular}


Çizelge 4'ün Devamı.

Continued Table 4

\begin{tabular}{|c|c|c|c|c|c|c|c|c|c|c|c|c|c|}
\hline \multirow[t]{2}{*}{$\begin{array}{l}\text { Profil } \\
\text { Profile }\end{array}$} & \multirow[t]{2}{*}{$\begin{array}{l}\text { Horizon } \\
\text { Horizon }\end{array}$} & \multirow[t]{2}{*}{$\begin{array}{l}\text { Derinlik } \\
\text { Depth } \\
(\mathrm{cm})\end{array}$} & \multirow[t]{2}{*}{$\begin{array}{l}\mathrm{pH} \\
\mathrm{pH}\end{array}$} & \multirow[t]{2}{*}{ 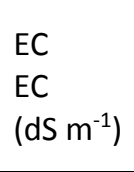 } & \multicolumn{4}{|c|}{$\begin{array}{l}\text { Suda Çözünebilir Anyonlar } \\
\text { Water Soluble Anions } \\
\left(\mathrm{me} \mathrm{l}^{-1}\right)\end{array}$} & \multicolumn{3}{|c|}{$\begin{array}{l}\text { Değişebilir Katyonlar } \\
\text { Exchangable Cations } \\
\left(\text { me } 100 \mathrm{~g}^{-1}\right)\end{array}$} & \multirow[t]{2}{*}{ 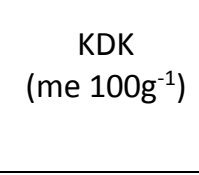 } & \multirow[t]{2}{*}{ ESP } \\
\hline & & & & & $\mathrm{CO}_{3}{ }^{-2}$ & $\mathrm{HCO}_{3}^{-}$ & $\mathrm{Cl}^{-}$ & $\mathrm{SO}_{4}^{-2}$ & $\mathrm{Na}^{+}$ & $\mathrm{K}^{+}$ & $\mathrm{Ca}^{++}+\mathrm{Mg}^{++}$ & & \\
\hline \multirow{3}{*}{ P5 } & A1g & $0-10$ & 8.27 & 18.11 & 0.64 & 2.26 & 70.30 & 275.93 & 34.72 & 0.61 & 21.94 & 57.27 & 60.62 \\
\hline & $2 \mathrm{Cg}$ & $10-25$ & 8.13 & 17.49 & 0.12 & 0.90 & 64.80 & 119.87 & 30.57 & 0.89 & 21.82 & 53.28 & 57.37 \\
\hline & $3 \mathrm{Cg}$ & $25+$ & 7.98 & 16.36 & 0.16 & 1.02 & 64.10 & 178.16 & 28.47 & 1.02 & 23.09 & 52.58 & 54.14 \\
\hline \multirow{7}{*}{ P6 } & Ap & $0-15$ & 8.17 & 0.34 & 0.48 & 2.38 & 2.00 & 2.16 & 0.83 & 0.72 & 17.47 & 19.02 & 4.34 \\
\hline & $\mathrm{A} 2$ & $15-35$ & 8.78 & 0.89 & 0.88 & 4.78 & 3.60 & 4.81 & 4.98 & 0.62 & 14.83 & 20.43 & 24.37 \\
\hline & $2 C$ & $35-60$ & 8.97 & 1.70 & 1.00 & 3.14 & 5.70 & 12.38 & 10.43 & 0.70 & 14.91 & 26.03 & 40.05 \\
\hline & $3 C 1$ & $60-99$ & 8.35 & 2.25 & 0.72 & 1.96 & 6.50 & 12.10 & 7.93 & 0.39 & 14.40 & 22.72 & 34.90 \\
\hline & $3 C 2$ & $90-110$ & 8.27 & 1.70 & 0.36 & 1.90 & 5.50 & 9.86 & 6.47 & 0.37 & 15.54 & 22.37 & 28.90 \\
\hline & $4 \mathrm{C} 1$ & $110-130$ & 8.29 & 1.45 & 0.52 & 1.92 & 5.70 & 8.80 & 5.68 & 0.34 & 15.70 & 21.72 & 26.16 \\
\hline & $4 C 2$ & $130+$ & 8.00 & 1.12 & 0.40 & 1.78 & 6.20 & 4.71 & 4.20 & 0.31 & 15.19 & 19.70 & 21.31 \\
\hline \multirow{6}{*}{ P7 } & $\mathrm{A} 1$ & $0-10$ & 7.59 & 3.28 & 0.12 & 0.86 & 2.20 & 35.90 & 1.19 & 0.61 & 49.67 & 51.46 & 2.30 \\
\hline & $2 \mathrm{C}$ & $10-21$ & 7.58 & 5.05 & 0.12 & 0.54 & 4.20 & 46.54 & 5.20 & 0.76 & 38.04 & 44.00 & 11.81 \\
\hline & $3 C$ & $21-46$ & 7.54 & 6.66 & 0.12 & 0.52 & 11.60 & 72.29 & 8.95 & 0.77 & 46.91 & 56.63 & 15.81 \\
\hline & $4 C$ & $46-88$ & 7.96 & 5.50 & 0.12 & 0.80 & 15.60 & 33.57 & 11.53 & 0.60 & 16.66 & 28.80 & 40.04 \\
\hline & $5 C$ & 88-104 & 8.67 & 4.61 & 1.16 & 3.44 & 13.80 & 18.22 & 9.22 & 0.43 & 17.34 & 26.99 & 34.17 \\
\hline & $6 \mathrm{Ckg}$ & $104+$ & 8.65 & 5.16 & 1.28 & 3.22 & 15.90 & 28.22 & 8.23 & 0.23 & 16.15 & 24.61 & 33.43 \\
\hline \multirow{7}{*}{ P8 } & $\mathrm{A} 1$ & $0-22$ & 8.02 & 0.37 & 0.56 & 3.20 & 2.10 & 0.46 & 1.38 & 0.56 & 22.85 & 24.79 & 5.55 \\
\hline & $A C$ & $22-48$ & 7.61 & 7.50 & 0.12 & 1.88 & 8.40 & 79.86 & 12.97 & 0.38 & 32.55 & 45.90 & 28.26 \\
\hline & $C$ & $48-79$ & 8.08 & 11.98 & 0.12 & 1.00 & 17.80 & 77.58 & 24.93 & 0.31 & 35.28 & 60.52 & 41.18 \\
\hline & $2 A$ & $79-106$ & 7.58 & 10.12 & 0.12 & 0.64 & 15.60 & 81.27 & 20.71 & 0.30 & 28.36 & 49.38 & 41.95 \\
\hline & $2 \mathrm{C} 1 \mathrm{~g}$ & $106-122$ & 8.02 & 4.17 & 0.72 & 1.58 & 10.50 & 46.30 & 12.47 & 0.33 & 18.59 & 31.40 & 39.73 \\
\hline & $2 \mathrm{C} 2 \mathrm{~g}$ & $122-156$ & 8.05 & 3.46 & 0.60 & 1.94 & 9.30 & 30.99 & 10.90 & 0.39 & 18.83 & 30.11 & 36.19 \\
\hline & $3 \mathrm{Cg}$ & $156+$ & 8.04 & 3.19 & 0.32 & 2.04 & 7.70 & 34.39 & 8.04 & 0.21 & 17.29 & 25.54 & 31.48 \\
\hline
\end{tabular}


GBS'de bulunan P1, P2 ve P3 profillerindeki organik madde miktarı KDS'de bulunan profillere göre daha düşük olmakla birlikte yüzey horizonlarında \%1.12-1.45 arasında, yüzey altı horizonlarda ise azalma eğilimi ile birlikte \%0.330.46 arasında değişim göstermektedir (Çizelge 4). P5 profilinin bulunduğu alanlarda herhangi bir tarımsal faaliyet ve yüzey horizonlarında bitki örtüsü olmamasına rağmen diğer profillere göre organik madde miktarı göreceli olarak daha fazla olmaktadır. Yüksek organik madde miktarının oluşumunda, farklı jeolojik devir/dönemde göl tabanına depolanmış olan organik madde ve gölün içerisindeki yaşamsal döngüsünü tamamlayarak göl tabanındaki lakustrin ana materyale karışmış olan canlı kalıntıların etkisi olabileceği düşünülmektedir. KDS'de bulunan P4 ve P7 profillerinde organik madde miktarının yüksek oluşumunda ise özellikle yüzey horizonlarında yetişmiş olan doğal tek yıllık otsu bitkilerin etkili olduğu düşünülmektedir. P4 ve P7 profillerindeki organik madde miktarında alt horizonlara doğru önemli orandaki azalmalar ise tespitimizi güçlendirmektedir. P6 profilindeki organik madde \%0.32-1.86 arasında değişmekle ve alt horizonlara doğru azalma eğilimindedir (Çizelge 4). P8 profilinde ise organik madde miktarında profil boyunca düzensiz artış ve azalışlar tespit edilmiştir. Söz konusu bu farklıığın nedeni ise, litolojik kesilmeye bağlı olarak her bir katmanın faklı olması ve her bir katmanın özellikle kuzey ve kuzeydoğu istikametinden mevsimlik/sürekli yan dereler ve akarsular tarafından organik maddece zengin yüzey ve yüzey altı horizonlarının taşınıp göl tabanına depolaması sonucunda oluşmasıdır. KDS'de bulunan profillerde organik madde ve kil miktarının GBS de bulunan bulunan profillere göre göreceli olarak daha fazla olduğu tespit edilmiştir. Organik madde ve kil miktarlarına bağlı olarak katyon değişim kapasitesi GBS'de bulunan profillerde $13.69-36.33$ meq $100 \mathrm{~g}^{-1}$ arasında değişirken KDS'deki profillerde 13.75-60.52 meq $100 \mathrm{~g}^{-1}$ arasında değişmektedir.

GBS'de bulunan profillerdeki $\mathrm{pH}$ değerleri; $\mathrm{P} 1$ 'de 7.73-8.33, P2'de 8.80-9.44 ve $\mathrm{P} 3^{\prime}$ de ise
8.11-9.53 arasında değişmektedir. Özellikle P2 profili göl tabanı üzerinde gelişen topraklar arasında en fazla $\mathrm{pH}$ seviyesine sahipdir. KDS'de bulunan profillerde ise gölden uzaklaştıkça $\mathrm{pH}$ değeri azalmakta ve 7.57-8.67 arasında değişmektedir. Görüldüğü üzere KDS'de bulunan profillerin $\mathrm{pH}$ değeri GBS'de bulunan profillere göre daha düşüktür. KDS'de bulunan P5 profili 16.36-18.11 dS $\mathrm{m}^{-1}$ arasında değişen EC değeri ile en yüksek tuzluluğa sahipdir. KDS bulunan diğer profillerde ise gölden uzaklaştıkça EC değerlerinde azalmakta ve 0.37-11.98 dS $\mathrm{m}^{-1}$ arasında değişmektedir. Güney batı sahilinde (GBS) ise en yüksek değer 1.34-3.72 dS $\mathrm{m}^{-1}$ arasında değişmekle birlikte $\mathrm{P} 2$ profilinde tespit edilmiştir. P1 profilinde tuzluluk riski bulunmamaktadır. P3 profilinde ise sadece $6 \mathrm{C}$ horizonunda $\left(2.18 \mathrm{dS} \mathrm{m}^{-1}\right)$ tuzluluk riski bulunmaktadır. Bohn ve ark., (1977) topraktaki yüksek tuz konsantrasyonunun, bitkilerin besin alımını ve metobolizmasını bozarak bitkiler üzerinde toksik iyon (bor, kor ve sodyum vb.) etkisi ve kök bölgesinde osmotik basınç dengesini bozarak bitkilerin topraktan su alımını engellediğini bildirmişlerdir.

GBS'de bulunan P2 profili çevresindeki diğer toprak profillerine (P1 ve P3) göre daha çukur bir alanda bulunmaktadır. Topoğrafyadaki bu çukurluk, gelen yüzey sularında çözünmüş olan anyonların ağırıklı olarak bu profil ve çevresinde birikmesine neden olmaktadır. GBS' de bulunan P1, P2 ve P3'de profilleri arasında eriyebilir anyonların

konsantrasyonları değerlendirildiğinde; en fazla $\mathrm{CO}_{3}{ }^{-2}$ miktarı 0.92$2.96 \mathrm{me} \mathrm{l}^{-1}, \mathrm{HCO}_{3}^{-}$miktarı 3.44- $6.82 \mathrm{me} \mathrm{l}^{-1}, \mathrm{Cl}$ miktarı 4.20-15.00 me $\mathrm{I}^{-1}$ ve $\mathrm{SO}_{4}^{-2}$ miktarı 2.64$22.60 \mathrm{me} \mathrm{I}^{-1}$ arasında değişen değerler ile birlikte P2 profilinde tespit edilmiştir. Eriyebilir anyonların konsantrasyonlarının P1, P2 ve P3 profillerinde yüzey horizonlarından alt horizonlara doğru artış eğiliminde oldukları saptanmıştır. KDS'de bulunan P4, P5, P6, P7 ve P8 profilleri arasında, eriyebilir anyonların konsantrasyonları değerlendirildiğinde ise; en fazla $\mathrm{CO}_{3}{ }^{-2}$ miktarı $0.12-1.28 \mathrm{me} \mathrm{l}^{-1}$ ile P7'de, en fazla $\mathrm{HCO}_{3}{ }^{-}$miktarı 1.90-4.78 me ${ }^{-1}$ ile $\mathrm{P}^{\prime} \mathrm{da}$, en fazla $\mathrm{Cl}$ miktarı 64.10-70.30 $\mathrm{me}^{-1}$ ve $\mathrm{SO}_{4}^{-2}$ miktarı 119.87-178.16 me $\mathrm{I}^{-1}$ arasında 
değişen değerleri ile P5 profilinde tespit edilmiştir. Beyhan ve ark., (2007) ve Gülle ve ark., (2010) tarafından yapılan bir araştırmalarda, Burdur Gölü suyunun mevsimsel yağış, buharlaşma, göle su taşıyan mevsimlik/sürekli akarsuların artan veya azalan su debilerine ve numunenin alındığı mekana göre değişiklik göstermekle birlikte $\mathrm{pH}$ ve EC değerlerinin, göl suyunun karbonat, bikarbonat, klorür, sülfat anyonları ve katyon konsantrasyonlarının ise oldukça zengin olduklarını ve her geçen yıl konsantrasyonlarının artığını tespit etmişlerdir. Aynı zamanda Gözükara ve ark., (2019a) tarafından Burdur Gölü' havzasında alüviyal fanlar üzerinde açılan toprak profillerinde Gölün güncel sınırına daha yakın olan profillerde $\mathrm{pH}$ ve EC değerleri, eriyebilir anyon ve değişebilir katyon konsantrasyonlarında artış tespit etmişlerdir. Araştırmacıların bu bulguları, eski göl tabanı üzerinde gelişen toprakların $\mathrm{pH}, \mathrm{EC}$ ve eriyebilir anyon konsantrasyonlarında gölün güncel sınırlarına yaklaştıkça artış göstermesinin ve KDS ile GBS'deki profillerdeki meksansal farklılıkların nedenlerini çok net bir şekilde desteklemektedir. Görüldüğü üzere eski göl tabanı üzerinde gelişen toprakların (özellikle KDS'de bulunan profillerde) güncel göl sınırına yaklaştıkça $\mathrm{EC}, \mathrm{pH}$ ve eriyebilir anyon konsantrasyonları toprak özelliklerini bozacak ve bitki yetiştiriciliğini (doğal veya kültürel) kısıtlayacak kadar şiddetlenmektedir. Bu sonuçlar eski göl tabanı üzerinde gelişen toprakların EC, $\mathrm{pH}$ ve eriyebilir anyon konsantrasyonlarının hem toprakların genetiksel özellikleri hemde göl suyu ile etkileşimi sonucunda şekillendiği göstermektedir. Her geçen yılda göl suyunun katyon konsantrasyonlarında artış olduğunu tespit etmişlerdir. GBS'de incelenen profiller arasında P1 profilinin horizonlarının tamamında değişebilir $\mathrm{Ca}^{++}+\mathrm{Mg}^{++}$ konsantrasyonu, P2 profilinde A1 horizonu hariç diğer horizonlarda $\mathrm{Na}^{+}$konsantrasyonu ve $\mathrm{P3}$ profillerinde ise sadece $8 \mathrm{C}$ horizonundaki $\mathrm{Na}^{+}$ konsantrasyonu diğer katyonlara göre daha yüksektir. KDS'de bulunan P4, P5, P6, P7 ve P8 profilleri arasında ise sadece $P 5$ profilinin tüm horizonlarında $\mathrm{Na}^{+}$konsantrasyonu diğer katyonlara göre daha yüksektir. GBS ve KDS'deki profillerde $\mathrm{Na}^{+\prime} u n$ baskın olmamasına rağmen profillerdeki $\mathrm{Na}^{+}$miktarı $\mathrm{Ca}^{++}+\mathrm{Mg}^{++}$miktarına çok yakındır. Söz konusu bu durum GBS ve KDS'de bulunan profillerin horizonlarındaki ESP değeri ile de desteklenmektedir. GBS'de bulunan profiller arasında en fazla ESP değerleri sırasıyla 2.88-56.40 ile P2 profilde tespit edilirken KDS'de bulunan profiller arasında en fazla ESP değerleri ise 54.1460.62 arasında değişen değerler ile P5 profilinde tespit edilmiştir. Toprakların sürdürülebilir kullanımına engel olan en önemli faktörlerden birisi de değiş̧ebilir $\mathrm{Na}^{+}$miktarıdır. Toprakta değişebilir katyonlardan $\mathrm{Na}^{+\prime}$ un artışı özellikle toprakların fiziksel özelliklerinin bozulması sonuncunda toprakların havalanması, geçirgenliğini, ayrışmasını ve bitki gelişimine zarar vermektedir. Yüksek tuzluluk ve düşük ESP değeri toprak özelliklerini iyi yönde etkilerken aksine düşük tuz yüksek ESP değeri toprakta geçirgenliği ve işlenebilirliği önemli ölçüde zorlaştırmaktadır (Rhoades ve ark., 1992; Rhoades, 2012). Araştırmacının bu verileri KDS ve GBS'de eski göl tabanı üzerinde gelişen ESP değerleri yüksek olan profillerde aynı zamanda tuzluluğun (EC) da yüksek olmasının toprakların fiziksel özelliklerinde (kıvam ve strüktür) olabilecek olumsuzlukları kısmen önlemiş olmasının nedenlerini açıklamaktadır. Bu sonuçlar eski göl tabanı üzerinde gelişen toprakların (GBS ve KDS'de) değişebilir katyon konsantrasyonlarında (özellikle $\mathrm{Na)}$ gölün güncel sınırına yaklaştıkça artışlar belirlenmiştir. Beyhan vd. (2007) her geçen gün göl suyunun katyon konsantrasyonlarında artış olduğunu tespit etmişlerdir. Araştırmacıların bu tespitleri değişebilir katyon konsantrasyonlarında (özellikle $\mathrm{Na}^{+}$) gölün güncel sınırına yaklaştıkça artışların nedenlerini açıklamaktadır. Araştırmacıların tespitleri ve bulgularımız sonucunda değişebilir katyon konsantrasyonlarının hem toprakların genetiksel özellikleri hemde göl suyu ile etkileşimi sonucunda şekillendiği göstermektedir. 


\section{Sonuçlar}

Kuvaterner yaşlı eski göl tabanlarında lakustrin ana materyaller üzerinde gelişmekte olan P1, P2, P3, P4, P6, P7 ve P8 profillerinin yüzey ve yüzey altı horizonlarında pedogenetik bir faaliyet olarak organik maddenin birikimi ve mineralizasyonu ile birlikte belirli düzeyde toprak oluşumu ve profil gelişimi tespit edilmiştir. Jeogenetik proseslerin bir gereği olarak bu alanlarda biriktirilmiş olan çeşitli kil minerallerin kolloidal etkileri sonucunda bu topraklarda A horizonları oluşmuş ve bu horizonlarda çoğunluğu orta irilikte ve orta dayanıma sahip yarı köşeli blok strüktürler de gelişebilmiştir. Fakat P5 profilinin bulunduğu alanlar çok yakın zamanda (yaklaşık 10 yıl önce) sudan kurtulmuş olmasından dolayı henüz bu alanlarda toprak oluşumu ve profil gelişimi gözlemlenmemiştir. Profillerin tamamının morfolojik tanımlamalarında ayrışma sonucu oluşan primer $\mathrm{CaCO}_{3}$ 'lar veya sekonder ayrışma ürünü olan $\mathrm{CaHCO}_{3}$ gözlemlenmemiş olmasına rağmen $\mathrm{P6}, \mathrm{P} 7$ ve $\mathrm{P} 8$ profillerinde kireç miktarında sınırlıda olsa alt katmanlara doğru hareketlilik belirlenmiş̧ir. Keza profillerdeki ayrışma-değişimdönüşüm işlemlerinin bir sonucu olarak kimi profillerin (GBS'de bulunan P1, P2 ve P3) özellikle yüzey horizonlarında renkte kısmen kırmızılaşmalar da gözlemlenmiştir. Renk ile açıklanan bu pedolojik gelişim, GBS ve KDS bulunan toprak profillerinde güncel göl sınırından uzaklaştıkça strüktür oluşumundaki artış ile desteklenmektedir. $\mathrm{Bu}$ tespitlerin tamamı değerlendirildiğinde, profillerin kuvaterner dönemin özellikle holosen bölümü olarak verilmiş olan yaşları dikkate alındığında genç profil özellikleri sahip olması yönündeki beklentimiz profillerde tespit edilen A-C olan horizon dizilimi ve sınırlı pedogenetik ayrışma-değişim-dönüşüm ile desteklenmiştir. Özelliklede Burdur Gölü’nün güncel göl sınırlarına yaklaştıkça pedogenetik ayrışma-değişim-dönüşümün oldukça azaldığı ve toprak işlemeyi ve bitkisel üretimi sınırlandırıcı kil içeriği, $\mathrm{pH}$ ve EC değerleri ile suda eriyebilir anyon ve katyon konsantrasyonlarında önemli artışlar tespit edilmiştir. Hatta bu sınırlandırıcı faktörler özellikle Burdur Gölü'nün dinamik su seviyesindeki azalmalar sonucunda (1975-2017 yılları arasında) açığa çıkan $80.90 \mathrm{~km}^{2}$ eski göl tabanlarında lakustrin ana materyal üzerinde gelişen toprakların morfolojik, fiziksel ve kimyasal analiz sonuçları doğrultusundaki pedolojik gelişime göre üzerinde tarım yapmaya elverişli olamayacak kadar şiddetlidir.

\section{Teşekkür}

Bu çalışma, FBA-2017-2800 numaralı Araştırma Projesinin bir bölümüdür. Katkılarından dolayı Akdeniz Üniversitesi Bilimsel Araştırma Projeleri Yönetim Birimine teşekkür ederiz.

\section{Kaynaklar}

Altunbaş, S. ve Sarı, M. (2010). Türkiye ölçeğinde sulak alan yönetim planlarının durumu; Eğirdir gölü yönetim planı örneği. I. Ulusal Toprak ve Su Kaynakları Kongresi, Eskişehir, s: 34.

Altunbaş, S. ve Sarı, M. (2011). Kurutulan kestel gölünden kazanılan toprakların bazı özellikleri ile üretim potansiyelleri arasındaki ilişkiler. Akdeniz Üniversitesi. Ziraat Fakültesi Dergisi, 24(1),61-65.

Atalay, i. (1977). Burdur havzası ve çevresinin jeomorfolojik gelişimi (Geomorphological evaluation of the Burdur Basin and its surroundings. Jeomorfoloji Dergisi, 6, 93-110.

Atalay, í. (2017). Türkiye Jeomorfolojisi. Meta Basım, İzmir.

Ataol, M. (2010). Burdur gölü'nde seviye değişimleri. Coğrafi Bilimler Dergisi, 8 (1), 77-92.

Ayyıldız, A. (1990). Sulama suyu kalitesi ve tuzluluk problemleri. Ankara Üniversitesi, Ziraat Fakültesi Ders Kitabı 344, Ankara.

Beyhan, M., Sahin, S., Keskin, M.E., Harman, İ.B. 2007. Effects of Long Period Water Level Changing to Water Quality and Heavy Metals in Lake Burdur. Süleyman Demirel University, Journal of Natural and Applied Sciences. 11(2): 173-179.

Black, C. A. (1965). Methods of soil analysis Part 2, Amer. Society of Agronomy Inc., Publisher Madisson, Wilconsin, U.S.A., 1372-1376.

Bohn. H.L., McNeal L.B. ve O' Connor, A.G. (1977). Soil chemistry. A Wiley Interscience Publication. John Wiley and Sons, 223-240 Newyork, Chishester.

Bouyoucos, G.J. (1955). A recalibration of the hydrometer method for making mechanical analysis of the soils. Agronomy Journal, 4 (9), 434.

Bozcu M., Yağmurlu F. ve Şentürk M. (2007). Fethiye-Burdur fay zonunun bazı neotektonik ve paleosismolojik özellikleri, GB-Türkiye. Jeoloji Mühendisliği Dergisi, 31 (1), 25-46.

Bower, C.A. (1959). Cation exchange equilibrium in soils. Affected by sodium salts. Soil Science, 88, 32-35.

Erol, O. (1980). Anadolu'da Kuaterner pluvial interpluvial 
koşullar ve özellikle iç Anadolu'da son buzul çağından bugüne kadar olan çevresel değişimler. Coğrafya Araştırmaları Dergisi, 9, 5-16.

Girgin, S., Kazancl, N. ve Dügel, M. (2004). On the limnology of deep and saline lake Burdur in Turkey. Acta Hydrochimica et Hydrobiologica, 32(3), 189-200.

Gözükara, G. ve Altunbaş, S. (2016). Lakustrin materyal üzerinde gelişen toprak özellikleri. 3. Ulusal Tarım Kongresi, Afyon. 05 - 08 Ekim. s.81.

Gözükara, G., Altunbaş, S. ve Sarı M. (2017). Determination of land change near the burdur lake by using remote sensing and geographic Information systems. 5th International Participation Soil and Water Resources Congress, Kırklareli. s.24.

Gözükara G., Altunbaş S. ve Sarı M. (2018). Evaluation of the effect of some climatic parameters on timedependent spatial variation of lake burdur; 19752017. 2017. International Ecology 2018 Symposium. Kastamonu. s.68.

Gözükara, G. (2019). Eski göl tabanlarındaki zamansal ve mekansal değişimlerin toprak oluşumuna etkileri. Akdeniz Üniversitesi, Fen Bilimleri Enstitüsü, Toprak Bilimi ve Bitki Besleme Anabilim Dalı, Doktora Tezi.

Gözükara, G., Altunbas, S., Sari, M. (2019a). Mekansal değişimin alüviyal fanlar üzerinde oluşan toprakların özelliklerine etkisi. Mediterrenean Agricultural Sciences, 32(3): 425-435.

Gözükara G, Altunbaş S, Sarı M (2019b). Burdur Gölü'ndeki seviye değişimleri sonucunda ortaya çıkan lakustrin materyalin zamansal ve mekansal değişimi. Anadolu Tarım Bilimleri Dergisi, 34(3): 386-396.

Gülle, I., Turna, I.I., Güçlü, S.S., Gülle, P., Güçlü, Z. 2010. Zooplankton seasonal abundance and vertical distribution of highly alkaline Lake Burdur, Turkey. Turkish Journal of Fisheries and Aquatic Science, 10: 245-254.

Fox, R.L., Olson, R.A. and Rhoades, H.F. (1964). Evaluating the sülfür status of soil by plants and soil test. Soil Sci, Soc. Am. Proc, 28,243-246.

Furquim, S.A.C., Santos, M.A., Vidoca, T.T., Babino, M.A. ve Cardoso, E.L. (2017). Salt-affected soils evolution and fluvial dynamics in the Pantanal wetland, Brazil. Geoderma, 286, 139-152.

Jackson, M. C. (1967). Soil chemical analysis. Prentice Hall of India Private'Limited, New Delhi.

Jenkins, D.A. ve Jones, R.G.W. (1980). Trace Elements in Rock, Soil, Plant and Animal: Introduction. In: Davies, B.E. (Ed), Applied Soil Trace Elements. John Wiley and Son Ltd., pp. 1-20.

Johnson, C.M. ve A. Ulrich (1959). II. Analytical methods for use in plant analysis. California Agriculturel Experiment Station. Bull. 766.

Karaman, M. E. (1990). Isparta güneyinin temel jeolojik özellikleri. Türkiye Jeoloji Bülteni, 33, 57 - 67.

Kacar, B. (1995). Bitki ve toprağın kimyasal analizler: III. Toprak Analizleri. A. Ü. Ziraat Fakültesi Geliştirme Vakfı Yayınları No: 3.

Kahraman, N. (2013). Water receding in Burdur Lake and solution proposals. 3rd

Keskin, M.E., Taylan E.D. and Aslanbaş T. (2015). Eğirdir ve Burdur Gölleri su seviyelerinde olasi azalma eğilimleri. 4. Su Yapıları Sempozyumu. Antalya.

Kış, M., Erol, O., Şenel, S. ve Ergin, M. (1998). Prelimnary results of radiocarbon dating of coastal deposits of the pluvial lake of Burdur, Turkey. Journal of Islamic Academy of Sciences, 2, 37-40.

Mutlu, H.H. (2010). Eski konya gölü kuvaterner terasları üzerinde oluşan toprakların jeokimyasal özellikleri ve ayrışma oranları. Selçuk Üniversitesi, Fen Bilimleri Enstitüsü, Toprak Bilimi ve Bitki Besleme Anabilim Dalı, Yüksek Lisans Tezi.

Owliaie, H., Ghiri, M.N. ve Shakeri, S. (2018). Soil-landscape relationship as indicated by pedogenesis data on selected soils from Southwestern, Iran. Eurasian Journal of Soil Science, 7(2), 167-180.

Rhoades, J.D., Kandiah, A. ve Mashali, M.A. (1992). The Use of saline waters for crop production. FAO irrigation and Drainage paper. 48. Rome.

Rhoades J.D. (2012). Diagnosis of Salinity Problems and Selection of Control Practices: An Overview. In: Wallender WW., Tanji K.K. (Eds.) Agricultural Salinity Assessment and Management. American Society of Civil Engineers, USA.

Sarı, M., Altunbaş, S., Sönmez, N.K. ve Emrahoğlu, E.I. (2003). Farklı fizyografik üniteler üzerinde yer alan eski Manay göl alanı topraklarının özellikleri ve potansiyel üretkenlikleri. Akdeniz Üniversitesi Ziraat Fakültesi Dergisi, 16(1), 7-17.

Sarı, M. (2015). Taşınmış ana materyal ile yer şekilleri arasındaki ilişkiler. (Ed. Şenol S., Küsek G., Sarı M., Kurucu Y.) Toprak Etüd Haritalama El Kitabı. Ankara. S.52-109.

Sarp, G. ve Ozcelik, M. (2017). Water body extraction and change detection using time series: $A$ case study of Lake Burdur, Turkey. Journal of Taibah University for Science, 11, 381-391.

Soil Survey Division Staff. (1993). Soil Survey Manual. USDA Handbook 18, US Gov. Print. Washington DC.

Soil Survey Laboratory Manuel. (2004). Soil Survey Laboratory Methods Manual. USDA Natural Resources Conservation Service. Soil Survey Investigations Report No 42. Washington D.C., USA.

Soil Survey Manuel. (2017). United states department of agriculture. Agriculture handbook. No:18.

Şener, E. ve Morova N. (2011). Modeling of water level changing of burdur lake with fuzzy logic and linear regression analysis. Süleyman Demirel Üniversitesi, Fen Bilimleri Enstitüsü Dergisi, 15(1),60-66.

Şenol, S. (2015). Toprak Etüd Haritalama El Kitabı. (Ed. Şenol S., Küsek G., Sarı M., Kurucu Y.). Ankara. S.1-25.

Tudryn, A., Tucholka P., Özgür N., Gibert E., Elitok O., Kamaci Z., Massault M., Poisson A. ve Platevoet B. (2013). A 2300-year record of environmental change from SW Anatolia, Lake Burdur, Turkey. J Paleolimnol, 49, 647-662. 